\title{
BIOFACIES MODEL FOR IDENTIFICATION OF PALEODEPTH TRENDS, MAXIMUM FLOODING SURFACES AND MARINE CONDENSED SECTIONS IN LATE CARBONIFEROUS AND EARLY PERMIAN FOURTH-ORDER CYCLOTHEMIC-SCALE DEPOSITIONAL SEQUENCES IN NORTH AMERICA
}

\author{
BOARDMAN*, Darwin R., II, Dept. Of Geology, Oklahoma State University, Stillwater, OK \\ 74078-0451, U.S.A.; WARDLAW, Bruce R., U.S. Geological Survey, 926A National Center, \\ Reston, VA 22092-0001, U.S.A.; NESTELL, Merlynd K., Dept. Of Geology, Univ. Of Texas at \\ Arlington, Arlington, TX 76019-0049, U.S.A.; KNOX, Larry W., Dept. Of Earth Sciences, \\ Tennessee Technological Univ., Cookeville, Tennessee, 38505, U.S.A.
}

Foraminifers, ostracodes, conodonts, and radiolarians were used to develop a nearshore to offshore biofacies model for Late Carboniferous-Lower Permian cyclothemic-scale Fourth Order Sedimentary Sequences from North America. Nearshore marginal marine strata are characterized by a low diversity of microfossil assemblages dominated by Geisina ostracodes, no conodonts, and rare Thurammina foraminifers. Nearshore normal marine strata contain a Cavellina ostracode biofacies, Adetognathus/Sweetognathus conodont biofacies, and encrusting foraminifers along with Ammodiscus cf. A. semiconstrictus var. regularis. Intermediate depth (open mid-shelf) strata contain an Amphissites ostracode biofacies, Idiognathodus-Streptognathodus conodont biofacies, and foraminifers consisting of Tetrataxis, Globivalvulina, large paleotextularids (Climacammina, Deckerella), endothyranellids (Endothyra, Endothyranella), Ammobaculites, and fusulinaceans. Deep-shelf marine strata contain a high diversity pelagic microfossil assemblage but a reduced diversity benthic microfossil assemblage containing a Mammoides and Healdia ostracode biofacies, Gondolella/Neogondolella-Idioprioniodus conodont biofacies, an AmmodiscusReophax foraminifer biofacies, and radiolarians. The high diversity pelagic fauna coupled with a reduced diversity benthic fauna is apparently the result of a paleo-oxygen gradient associated with a widespread oxygen minimum zone that developed on the shelf during maximum or near maximum transgression. During lowstands oxygen poor waters were restricted to continental margins and very deep intracratonic basins and then expanded and migrated onto the shelf regions and shallow intracratonic basins during transgression, and were best developed during maximum transgression.

Late Carboniferous and Early Permian marine condensed sections that developed as a result of major transgressions apparently associated with fourth-order $(400,000)$ orbital eccentricity cycles occur as black, fissile, commonly phosphatic shales characterized by diverse, and abundant (commonly in excess of 1,000 platforms $/ \mathrm{kg}$ ) conodont faunas, radiolarians, and ammonoids. These marine condensed sections serve as excellent subsurface marker beds due to their high natural gamma-ray signature on geophysical logs. These black fissile and phosphatic shales grade updip first into highly fossiliferous gray mudstones with minor phosphate and then into highly fossiliferous, glauconitic, wackestone carbonates with marine cements and abundant phosphatized molluscs. These updip maximum flooding surfaces represent the proximal expression of the marine condensed section as evidenced by their numbers of conodonts $/ \mathrm{kg}$ along with their associated biofacies. The conodont species contained in the marine condensed sections provide an excellent high resolution chronostratigraphic framework for intrabasinal as well as interbasinal correlation. 